\title{
SIFAT DAN PEREMPUAN- PERSPEKTIF ECO-FEMINISTIS
}

\author{
Erika Yola \\ Sekolah Tinggi Ilmu Sosial Dan Ilmu Politik Yaleka Maro \\ Email:erika01@gmail.com
}

\begin{abstract}
Abstrak
Perempuan memainkan peran penting dalam pengelolaan sumber daya alam, termasuk tanah, air, hutan dan energi, dan seringkali memiliki pengetahuan tradisional dan kontemporer yang mendalam tentang dunia alam di sekitar mereka. Perempuan memiliki hubungan yang berbeda dengan lingkungan, termasuk kebutuhan, tanggung jawab dan pengetahuan yang berbeda tentang sumber daya alam. Tetapi perempuan secara langsung dipengaruhi oleh degradasi lingkungan, penggundulan hutan, polusi dan kelebihan populasi, mereka menjadi lebih peduli terhadap masalah lingkungan. Beberapa gerakan yang diikuti perempuan adalah Gerakan Chipko, Gerakan Sabuk Hijau, Gerakan Navdanya dan Pengambilalihan Tanah Kenya. Vandana shiva, Wangari Maathai, Maria Cherkasova dan Rachel Carson adalah tokoh terkenal di seluruh dunia. Bahkan di Tamil Nadu, perempuan menyelamatkan lingkungan di dalam dan sekitar masyarakat. Ekofeminisme, mengacu pada perspektif perempuan dan feminisme tentang lingkungan, di mana dominasi dan eksploitasi perempuan terhadap orang-orang yang memiliki sumber daya yang buruk dan alam, berada di jantung gerakan eko-feminis. Dalam tulisan ini kita telah membahas tentang, bagaimana wanita menjalankan perannya untuk melindungi planet kita.

Kata kunci: Perempuan, Perlindungan, Lingkungan, Gerakan, Konservasi, Ekologi \& Feminis, Ekosistem
\end{abstract}

\section{Abstract}

Women play an important role in the management of natural resources, including land, water, forests and energy, and often have in-depth traditional and contemporary knowledge of the natural world around them. Women have different relationships with the environment, including different needs, responsibilities and knowledge about natural resources. But women are directly affected by environmental degradation, deforestation, pollution and overpopulation, they become more concerned about environmental problems. Some of the movements that the women participated in were the Chipko Movement, the Green Belt Movement, the Navdanya Movement and the Kenyan Land Acquisition. Vandana shiva, Wangari Maathai, Maria Cherkasova and Rachel Carson are

JURNAL PAPATUNG: Vol. 2 No. 1 Tahun 2019

ISSN: 2715-0186 
famous figures around the world. Even in Tamil Nadu, women save the environment in and around society. Ecofeminism, refers to the perspective of women and feminism on the environment, where the domination and exploitation of women against people who have poor resources and nature, is at the heart of the eco-feminist movement. In this article, we have discussed about how women carry out their roles to protect our planet.

Keywords: Women, Protection, Environment, Movement, Conservation, Ecology \& Feminism, Ecosystem

\section{A. PENGANTAR}

Saatnya bertindak! Dunia kita semakin panas menciptakan efek merusak bagi ekosistem. Sudah terlalu lama kita melupakan fakta bahwa bumi adalah tempat kehidupan yang melimpah karena keseimbangan ekologisnya. Ekofeminisme mengatakan bahwa, wanita lebih dekat dengan alam daripada pria. Wanita lebih mengasuh dan peduli, terhadap lingkungan. Seorang ekofeminis percaya pada hubungan langsung antara penindasan alam dan subordinasi perempuan. Istilah eko feminisme diciptakan oleh Feminis Perancis Francoise D Eaubonne pada tahun 1974. Ia mencoba menggambarkan tentang dominasi laki-laki. Ekofeminisme adalah gerakan sosial yang memandang penindasan terhadap perempuan dan alam, yang saling berhubungan. Di abad ke-20, wanita berjuang untuk melindungi satwa liar, makanan, udara, dan air. Makalah ini membahas tentang, gerakan lingkungan utama seperti gerakan Chipko, gerakan Sabuk Hijau, Navadanya dan tanah Kenya mengambil alih, dengan fokus pada konsep dan peran eko feminisme di dan sekitar India

\section{B. PEMBAHASAN \\ ALAM DAN WANITA}

JURNAL PAPATUNG: Vol. 2 No. 1 Tahun 2019

ISSN: 2715-0186 
Manusia membutuhkan waktu satu juta tahun untuk menghancurkan lingkungan yang sehat, tetapi alam membutuhkan 600 juta tahun untuk mengembangkan biosfer. Di permukaan bumi, baik di air maupun di darat, perubahan ini mengakibatkan pemiskinan sistem biologis dan kemunduran keanekaragaman hayati. Di atmosfer, peningkatan konsentrasi karbon dioksida menyebabkan pemanasan global, sementara polusi di stratosfer telah menggerogoti perisai zona vital. Perubahan ini diharapkan membuat kehidupan manusia semakin sengsara di masa yang akan datang. Wanita memiliki peran utama dalam menyelamatkan lingkungan. Wanita harus menciptakan kesadaran kepada orang yang tidak dikenal untuk sadar, mengenali dan mengendalikan masalah lingkungan dalam kehidupan mereka di masa depan.

Salah satu gerakan pencinta lingkungan pertama yang terinspirasi oleh perempuan, Gerakan Chipko. Kata itu berasal dari kata Hindi yang berarti "menempel". Raja memerintahkan beberapa pekerja untuk menebang pohon, tetapi Amrita Devi dan 84 penduduk desanya telah mengambil resiko untuk melindungi pohon di hutan agar tidak ditebang. Di desa Reni, perempuan mulai mengorganisir diri dalam beberapa kelompok, dan mulai mengancam para penebang pohon. Pada Oktober 1971, para pekerja mengadakan demonstrasi di Gopeshwar, untuk memprotes kebijakan departemen kehutanan. Pada akhir 1972, mereka melakukan demonstrasi dan pawai. Departemen kehutanan mengontrak penebangan 300 pohon, kepada Simon Company, yang merupakan produsen alat olahraga di Allahabad, untuk membuat raket tenis. Pada bulan Maret 1973, tukang kayu tiba di Gopeshwar, mereka dihadapkan di desa Mandal, di mana sekitar seratus penduduk desa dan pekerja sedang menabuh genderang dan meneriakkan slogan. Kontraktor dibatalkan dan sangam memutuskan untuk melakukan pelukan pohon, atau Chipko, sebagai sarana protes tanpa kekerasan. 
Warga desa memutuskan untuk memprotes tindakan pemerintah tersebut dengan memeluk pohon. Pada tanggal 25 Maret 1974, para penebang akan menebang pohon dan Gaura Devi, kepala desa Mahila Mangal Dal, di desa Reni, memimpin 27 perempuan desa ke lokasi tersebut dan menghadapi para penebang. Tetapi para penebang berteriak dan mengancam dengan senjata, ketika tiba-tiba para wanita mulai memeluk pohon, itu berlangsung hingga larut; para wanita sepanjang malam menjaga pohon dari penebang. Pemotong dan pemimpin dikembalikan, gerakan menyebar ke desa-desa lain dan lebih banyak orang bergabung dalam gerakan ini. Berita itu sampai ke ibukota negara bagian, di mana Menteri Utama Hemwati Nandan Bahuguna mengatur sebuah komite untuk menjaga berita tersebut, yang akhirnya memenangkan hati penduduk desa. Ini menjadi titik balik dalam sejarah perjuangan eko-pembangunan di wilayah itu dan di seluruh dunia. Para pemimpin menamakan aktivitas mereka, Gerakan Chipko. Orang-orang juga menyebarkan gerakan tersebut ke distrik lain. Gerakan ini meraih kemenangan, ketika pemerintah mengeluarkan larangan penebangan pohon di daerah Himalaya selama 15 tahun pada tahun 1980, oleh Perdana Menteri Indira Gandhi, sampai tutupan hijau dipulihkan sepenuhnya. Gerakan Sabuk Hijau, Salah satu gerakan terbesar dalam sejarah perempuan dan lingkungan, Gerakan Sabuk Hijau. Di Kenya, Wangari Maathai memulai organisasi pada tahun 1977. Upacara permulaannya sangat sederhana, beberapa wanita menanam beberapa pohon di halaman belakang rumah Maathai. Gerakan ini mendorong perempuan pedesaan untuk menanam pohon, memberantas deforestasi, dan memulihkan bahan bakar serta menghentikan erosi tanah. Ketika gerakan dimulai, lebih dari 51 juta pohon ditanam dan 30.000 perempuan dilatih di hutan, untuk melestarikan tanah. Di Kenya, beberapa kelompok termotivasi untuk mencegah kerusakan 
lingkungan dan memulihkan lingkungan yang rusak. Pekerjaan utama gerakan ini adalah pengentasan kemiskinan dan pelestarian lingkungan.

\section{Gerakan Navadanya}

Navadanya berarti Sembilan Benih yang mewakili sumber ketahanan pangan kolektif India. Gerakan tersebut memberi makan para petani, menanam tanaman, tanpa menggunakan bahan kimia apa pun. Ini telah menjangkau banyak petani dan 65 bank benih telah dibuat di India. Gerakan ini merupakan organisasi non-pemerintah yang mempromosikan pertanian organik, konservasi keanekaragaman hayati dan hak-hak petani untuk menyimpan benih. Vandhana Shiva adalah pendirinya, yang memulainya pada tahun 1984; dia memberikan arahan dan dukungan untuk melindungi biosfer.

\section{Pengambilalihan Tanah Kenya}

Di Kenya, perempuan berada di bawah tangan suami dan pemerintah, karena harus menanam kopi untuk keuntungan asing pada 1980-an. Mereka berperang melawan pemerintah, untuk mengirim kembali tanah itu untuk digunakan sendiri. Kemudian mereka mengakhiri protes, sebelum pemilihan nasional. Menurut Bank Dunia, 80 persen petani Kenya adalah wanita. Meskipun mayoritas, mereka masih memiliki banyak tantangan untuk diatasi, seperti mendapatkan kepemilikan tanah tempat mereka bekerja. Seorang perempuan petani pemilik tanah Linda Okal bekerja di ladang jagung di distrik Embu, Kenya melakukan ini dengan menggunakan tangan dan cangkulnya. . Dia telah merawat satu hektar dan seperempat lahan, dan juga sapi, kopi, pisang, dan kacang-kacangan. Tanaman terpenting di setengah hektar itu adalah jagung yang dia tanam setiap musim. Saat ini, lebih dari 80 persen pertanian di Kenya dijalankan oleh wanita. Maria Cherkasova adalah seorang jurnalis Rusia, ahli ekologi, dan direktur Center for Independent Ecological Programmers (CIEP). Dia terkenal karena 
mengkoordinasikan kampanye selama 4 tahun, untuk menghentikan pembangunan bendungan hidro-listrik di Sungai Katun. Setelah keterlibatan Cherkasova dalam gerakan mahasiswa tentang perlindungan lingkungan pada tahun 1960-an, dia mulai bekerja untuk Buku Data Merah, untuk Departemen Institut Perlindungan Lingkungan. Dia meneliti dan melestarikan spesies langka sampai dia menjadi editor Buku Data Merah Uni Soviet. Maria adalah salah satu pendiri Serikat Sosial-Ekologi, yang telah menjadi LSM ekologi terbesar di bekas Uni Soviet. Pada tahun 1990, ia menjadi direktur CIEP, yang mengatur dan mendorong kegiatan di berbagai bidang terkait ekologis, baik di bidang domestik maupun internasional. Cherkasova baru-baru ini telah mengalihkan fokusnya pada perlindungan hak-hak anak, untuk hidup di lingkungan yang sehat dan berbicara baik di dalam maupun di luar Rusia.

Rachel Carson adalah salah satu pencinta lingkungan yang luar biasa. Dia adalah seorang ilmuwan, penulis, dan ahli ekologi Amerika. Dia terinspirasi oleh guru biologi sehingga dia memilih jurusan dari bahasa Inggris ke biologi. Dia sangat tertarik dan fokus pada laut saat dia bekerja di Marine Biological Laboratories di Massachusetts. Penerbitan buku pertamanya, Under the Sea-Wind: a Naturalists 'Picture of Ocean Life, dilakukan pada tahun 1941. Ia menjadi Pemimpin Redaksi, Fish and Wildlife Service (FWS) pada tahun 1949. Buku keduanya adalah The Sea around Kami, telah memenangkan Penghargaan Buku Nasional.

Setelah Rachel Carson pensiun dari FWS, dia menjadi penulis penuh waktu. Buku terakhirnya tentang laut, The Edge of the Sea; pekerjaan ini difokuskan tentang efek bahan kimia dan pestisida terhadap lingkungan. Ketika dia telah menulis bukunya tentang lingkungan, Silent Spring, tentang apa yang telah dilakukan manusia terhadap alam dan akhirnya padanya, dan memulai gerakan lingkungan modern. Carson percaya 
bahwa, manusia dan alam saling bergantung satu sama lain. Ia berpendapat, kegiatan industri seperti penggunaan pestisida dapat merusak ekosistem bumi dan akan menimbulkan konsekuensi ekologis yang luas seperti masalah kesehatan manusia di masa depan. Saat ini, penelitian ilmiah telah menunjukkan konsekuensi ini.

Elaine Enarson adalah seorang penulis, sarjana, dan pendidik tentang wanita dalam bencana. Dari Amerika Serikat dan berbasis di Evergreen, Colorado, dia adalah anggota pendiri jaringan gender dan bencana, pengembang utama kursus kerentanan sosial untuk Federal Emergency Management Agency negaranya dan peneliti utama pada proyek kerentanan di Karibia.

Nandita Krishna adalah seorang sejarawan, pemerhati lingkungan, dan penulis di Chennai. Dia adalah seorang profesor dan pemandu penelitian untuk program Ph.D di Universitas Madras. Pada tahun 1981, ia memulai program pendidikan alam untuk guru dan siswa di Yayasan C.P.Ramaswami Aiyar. Pada tahun yang sama, ia menjadi Ketua Tamilnadu WWF India, ia memegang posisi ini hingga tahun 1996. Dia telah menjadi anggota Senat Universitas Madras, Otoritas Kebun Binatang Pusat, Dewan Satwa Liar Nasional, Dewan Lingkungan Nasional, Pemerintah India, Dewan Penelitian dan Pendidikan Kehutanan India dan Komite Orientasi Lingkungan untuk Pendidikan Sekolah, Kementerian Manusia Pengembangan Sumber Daya. Programnya adalah pengomposan vermi, kebun herbal, pengumpulan dan pemeliharaan bank benih melalui produk ramah lingkungan.

Krishnammal Jagannadhan adalah seorang pekerja sosial dari Tamil Nadu. Dia bekerja untuk perbaikan Dalit. Dia menentang industri yang mencemari air tanah. Dia adalah aktivis Gandhi. Dia menerima beberapa penghargaan untuk karyanya. 
Selama tahun 1992, dia bekerja untuk para pengangguran yang tidak memiliki tanah, dikirim dari industri. Industri telah mengambil lahan yang bisa diolah untuk perusahaan udang mereka dan juga membuat tanah menjadi asin dan mencemari air tanah. Mereka telah berjuang untuk mendapatkan air minum. Kemudian mereka menjual tanah dan pindah ke kota dan mengisi daerah kumuh perkotaan.

The Jagannathans mengorganisir gerakan desa LAFTI untuk menciptakan kesadaran menentang peternakan udang. Mereka mengajukan petisi ke Mahkamah Agung untuk mencari solusi atas masalah ini. Laporan itu menyebutkan semua tambak udang dilarang dalam jarak 500 meter dari pantai. Mahkamah Agung memerintahkan aturan yang melarang tambak udang tidak boleh bekerja di lahan yang bisa ditanami. Namun masih belum terselesaikan dan memperjuangkan masyarakat yang ramah lingkungan. Wanita memiliki peran utama dalam perlindungan lingkungan, kata M. Ramathal, Ketua Komisi Wanita negara bagian, di Tiruvarur. Wanita dapat menanam pohon muda di rumah mereka dan menggunakan air secara efisien. Dengan demikian mereka dapat berkontribusi untuk meminimalkan pemanasan global dan mengurangi perubahan iklim. Mereka harus berjanji untuk menghindari penggunaan plastik artikel dan hanya membeli barang konsumsi yang diperlukan. Periyar mengatakan, pendidikan yang diberikan kepada perempuan adalah pendidikan yang diberikan kepada seluruh keluarga dan bangsa. Peran perempuan sangat penting di banyak bidang dan mereka dapat membantu dalam melindungi lingkungan.

\section{KESIMPULAN}

Makalah ini telah membahas berbagai cara perempuan berpartisipasi aktif dalam perlindungan lingkungan dan pengelolaan sumber daya alam untuk memastikan 
penggunaan sumber daya lingkungan secara berkelanjutan. Wanita berbagi lingkungan seperti halnya pria. Melibatkan perempuan dalam melindungi lingkungan akan membantu masyarakat mengembangkan rasa tanggung jawab yang diperlukan untuk menjaga keseimbangan yang baik antara sumber daya manusia dan bumi. Partisipasi yang seimbang dan setara antara pria dan wanita dalam merumuskan dan melaksanakan kebijakan dan program sangat penting, kata Salvano Briceno, Direktur Strategi Internasional PBB untuk Pengurangan Bencana. Wanita harus diizinkan untuk berpartisipasi di tingkat lokal, regional, nasional, dan internasional dalam masalah lingkungan. Wanita sebagai pembawa dan pelestari kehidupan, sebagai mereka yang pertama kali membimbing anak-anak, harus menjadi yang terdepan dalam dedikasinya terhadap masalah lingkungan. Pendidikan lingkungan diperlukan bagi setiap warga negara untuk pembangunan berkelanjutan. Perempuan berpendidikan akan berkontribusi lebih signifikan untuk menjembatani kesenjangan antara lingkungan dan pembangunan. Lindungi lingkungan untuk mendapatkan air bersih, udara untuk pernafasan dan tanah bersih untuk budidaya. Ini diperlukan untuk kehidupan yang aman dan sehat untuk generasi sekarang dan masa depan. Keseimbangan ekologis merupakan aspek penting dari pendekatan baru untuk pembangunan bangsa, dan kepedulian perempuan terhadap kepentingan ekologi lokal sangat penting untuk proses pemberdayaan perempuan.

Tekanan penduduk telah meningkatkan migrasi laki-laki, yang pada gilirannya menambah beban pekerjaan pada perempuan. Jadi, tanggung jawab perempuan meluas dari tugas rumah tangga hingga bekerja di ladang juga. Perempuan memainkan peran kunci dalam perlindungan keanekaragaman hayati melalui berbagai tanggung jawab mereka. Mereka telah mengidentifikasi kebutuhan tidak hanya untuk melindungi 
keanekaragaman hayati, tetapi juga untuk menciptakannya kembali. Wanita India selalu terdepan dalam hal pencegahan polusi dan perlindungan, pelestarian, pelestarian, promosi dan peningkatan lingkungan. Mereka telah membuat pengorbanan yang lebih besar, telah menunjukkan cinta yang lebih besar dari pada manusia di bidang perlindungan lingkungan. Keinginan yang kuat, pengabdian dan dedikasi terhadap lingkungan yang lebih baik membuat wanita India menjadi pejuang melawan pencemaran lingkungan. Penting bagi kita untuk memastikan lingkungan yang sehat untuk generasi masa depan kita - setiap tetes air yang digunakan untuk membuat lautan adalah penting. Jangan biarkan dunia kita menjadi "Sekali waktu". Suatu hari kita akan bekerja untuk pohon dan menasihati orang untuk mengadopsi kebiasaan ramah lingkungan. Hal-hal kecil jika digabungkan bersama tentu dapat menghasilkan solusi yang lebih besar dan lebih baik.

\section{DAFTAR PUSTAKA}

"Major Role for Women in Environment Protection." T he Hindu 16 Sep 2009. Print.

Aditya, Sandeep Kumar. "Role of Women in Environmen tal Conservation." International Journal of Politic al Science and Development vol. 4.4(2016): 140-145. Print.

Asthana, D.K. Environment: Problems and Solutions. New Delhi: S.Chand \& Company Ltd, 1999. Print.

Chelala, Cesar. "Women's role key to saving Environme nt." China Daily 18 Oct 2011. Print.

Devi, Hemalatha. V. "Women in Environmental Protect ion." 20th WEDC Conference Colombo Sri Lanka (1994): 4 2-43. Print.

Dobscha, Susan."Women and the Environment: Applying Ecofeminism to EnvironmentallyRelated Consumption." NA- Advances in Consumer Research Vol 20. eds.Leigh McAlister and Michael L. Rothschild, Provo, UT (1993): 36-40. Print.

Manjunath, K.V. "Marching towards Sustainability- Ro le of Women in Environmental Conservation.” Internat ional Journal of Academic Research 2.6 (2015): 27-34. Print.

Sanyal, K. Ecology and Environment. Kolkata: Books and Allied (p) ltd, 2009. Print.

JURNAL PAPATUNG: Vol. 2 No. 1 Tahun 2019

ISSN: 2715-0186 
Seema. "Eco-Feminism and Environmental Movements in India." International Journal of Current Research 6.1 (2014): 4656-4660. Print.

Sharma, Renu and Kaushik, Baljit. Dr. "Role of Women in Environmental Conservation." EXCEL International Journal of Multidisciplinary Management Studies 1.2 (2011): 167-167. Print. 